\title{
A Dynamic Relationship between Consumer Confidence and Residential Property Price: Empirical Evidence for Malaysia
}

\author{
Nur Hafizah Ismail ${ }^{1 *}$ and Sabri Nayan ${ }^{1}$ \\ ${ }^{1}$ School of Economics, Finance and Banking, Universiti Utara Malaysia, 06010 Sintok, Kedah, Malaysia
}

*Email: hafizah19@live.com

\begin{abstract}
In recent years, the real estate market has become a major interest for economists and researchers. In general, property prices are influenced by the supply and demand of the real estate market. In addition to the individual's positive expectation of the real estate market would raise the demand for housing and hence, house price indexes would increase. This study provides new knowledge on how consumer confidence in the housing industry affects residential property prices in Malaysia. Previous studies on the effect of consumer perception towards residential property in Malaysia are scarce. Therefore, the objective of this study is to determine how consumer confidence affect residential property price in Malaysia. Our study differs by focusing on the effect of consumer confidence on the housing industry and macroeconomic drivers toward residential property prices in Malaysia over the period 2004:Q1 to 2018:Q4. By using the autoregressive distributed lag (ARDL) test, the empirical results have shown the presence of long-run adjustment and indicate that consumer confidence towards the housing industry and many macroeconomic variables significantly affect residential property prices. From this finding, we have suggested that government and policymakers should be able to understand consumer confidence in the housing industry to increase consumer satisfaction and to improve consumer sentiment towards the residential property market in Malaysia.
\end{abstract}

Keywords: Real Estate, Consumer Confidence, Macroeconomic, Autoregressive Distributed Lag (ARDL)

\subsection{INTRODUCTION}

The real estate market has been viewed as a key point of interest for economists and researchers. In general, property prices are influenced by the supply and demand of the real estate market. King (1990) indicates that people's good expectation of the real estate market would raise the demand for housing and hence, house price indexes would increase. According to Ciarlone (2015), several factors such as interest rate and income growth have been determined as significant factors affecting housing prices. Besides, a study done by Hashim (2010) has listed other several economic fundamentals that influenced the residential property price trends such as stock prices, housing supply, economic activity, and population growth. Apart from that, Chun (2017) has found that consumer confidence in the housing industry is another important key driver to the housing value and real estate finance markets.

Consumer confidence is speculation of consumer behaviour that is caused by psychological factors such as motivation and perception towards one particular issue (Rani, 2014). Furthermore, Chun (2017) reported that high consumer confidence in the real estate market shows that consumers would assume that there would be a steady rise in the residential property price. The movement of the consumer 
confidence index shows a signal for the real estate market, whereby in the market of real estate, consumers' interests in real estate fluctuate either increasing or decreasing (Realia Group, 2019).

According to Westpac Melbourne Institute Index of Consumer Sentiment (2015), a positive relationship between consumer confidence and house sales volume signals an increase in consumer sentiment towards the housing industry. Besides that, consumer's perceived economic situation especially on credit dynamic in both internal aspect (such as a financial situation) and external aspect (such as interest rates) could influence the decision process about entering the real estate market through financing facilities such as borrowings (Malovana, Hodula \& Frait, 2021). As a result, this might have caused the rate of real estate market value to increase which finally will drive residential property prices up and cause a housing bubble. However, the movement patterns of consumer confidence and residential property price may vary from time to time. For example, a study done by Mohd Daud and Marzuki (2019) found that there is a persistent increase in residential property prices although consumer confidence started to reach the low index level. Besides, consumer sentiment on the restrictive mortgage lending policy could promote fluctuations in residential property prices (White, 2015).

Households' perceptions and expectations are closely linked to macroeconomic conditions. Malovana, Hodula and Frait (2021) suggest that households' future spending is based on their sentiment towards current economic status. A country which has longer-term good macroeconomic outlook will influence the households to take on a mortgage loan rather than other consumer loans. Similarly, a study was done by Bordalo. Gennaioli and Shleifer (2018) show that macroeconomic factors affect households' confidence, and they often predict recent and current macroeconomic conditions to the future.

Among ASEAN-8 countries, the housing industry in Malaysia continues to be an important investment by households. Hashim (2010) reported that the residential property price and housing industry plays a major role in Malaysia's economy and business cycle in terms of the capital market, employment, and financial wealth. However, property cycle, overhang property, shortage of housing affordability, property value fluctuation, and house bubble are several critical issues of discussion in Malaysia's real estate market since decades ago (Ab Majid, Said \& Chong, 2017; Ismail, Karim \& Hasan-Basri, 2019; Ling, Almeida \& Wei, 2017; Yin, Hui Nee \& Senadjki, 2019). According to Ferlito (2018), the property crisis in Malaysia is associated with consumer confidence in the housing industry. Cheong, Ngui and Beatrice (2018) indicate that positive or negative consumer confidence in spending would affect their decision making to enter the property market in Malaysia. Consumer attitudes and intentions on residential property price movement will be able to inform the market about future real estate investment in Malaysia (Mohd Daud \& Marzuki, 2019). If consumer confidence falls, this will cause lower consumer spending, reduce the rate of economic growth and affect the development of Malaysia's housing industry.

In recent years, studies on consumer confidence in property prices have been emerging as it provides a framework to understand the behaviours of consumers in the real estate market (Chun, 2017; Ferlito, 2018; Jin, Soydemir \& Tidwell, 2014; Marcato \& Nanda, 2016; Mohd Daud \& Marzuki, 2019; White, 2015). These studies provide the framework to understand the behaviour of consumers towards the housing industry. However, existing studies that investigate the relationship between consumer confidence and residential property prices in Malaysia are limited (Mohd Daud \& Marzuki, 2019). To the best of our knowledge, there is no study analysing the effect of consumer confidence and macroeconomic drivers on residential property prices in Malaysia. Therefore, it is pertinent to study how consumer confidence in the housing industry affects the residential property price in Malaysia. Thus, the objective of this study is to determine how consumer confidence affect residential property price in Malaysia.

This is in line with the government policy under National Housing Policy 2.0 (2018-2025) whereby to increase consumer confidence among Malaysians in the residential property market with several housing initiatives to increase the housing affordability among young households and to enhance 
the sustainability of the quality of life of the people. Furthermore, this study has proposed appropriate policies on the development of the consumer sentiment index as one of the useful measurements to represent consumer confidence towards the demand and supply of residential property in the real estate market.

The remainder of the paper is organised as follows. Section 2 discusses the related literature. Section 3 highlights the research method. Section 4 discusses the empirical findings and the final section concludes the paper.

\subsection{LITERATURE REVIEW}

This section provides a review of relevant theory and previous empirical studies regarding the buyer behaviour model and the effect of consumer sentiment and macroeconomic drivers on residential property prices.

\subsection{Theory of Buyer Behaviour Model}

The theory of the Buyer Behaviour Model was introduced by Howard and Sheth in 1969 and later, Loudon, Albert and Della Bitta (1993) help to establish the model. This theory explains the Hypothetical Constructs which can be categorised under Perceptual Constructs and Learning Constructs (including sensitivity to information, perceptual bias, and search for information). These categories serve to determine the scope to which the buyer considers upcoming purchases by seeking the latest information. The majority of real estate buyers will consider high involvement products that necessitate decision-making (Gibler \& Nelson, 1998). The authors trace the behaviour of individual buyers from the moment they recognise a need through their search for product details, assessment of alternatives, purchasing, and final assessment of the implications. The premise is that a series of information processing precedes a buying act. This includes a cognitive function in forming opinions, an emotional dimension in creating positive or negative perceptions, and attitudes and a reaction through being motivated and confident in selecting and purchasing the property.

Given the price and income limits, buyers look forward to making property purchase options that optimize their utility and wealth (Ariyawansa, 2010). A positive buyer behaviour on property purchase behaviour will cause a growth in demand for housing which pushed up residential property prices (Chia et al., 2016). According to Liew and Haron (2013), property price movements are inherent in the regional demographics and regional economics, such as population, Gross Domestic Product (GDP), housing finance, inflation rate, Real Property Gains Tax (RPGT), and cost of construction.

\subsection{Effect of Consumer Confidence Towards Residential Property Prices}

Kamakura and Gessener (1986) were the first to investigate the impact of consumer sentiment on the property market. Later, Goodman (1994), Dua and Smyth (1995) and Weber and Devaney (1996) continued to study the relationship between consumer confidence and the housing market. For example, Goodman (1994) studied the effects of consumer psychology on the construction of new residential houses in the property market. Meanwhile, Dua and Smyth (1995) studied the consumer's intention to purchase residential property on the volume of the transaction of existing properties. Jin and Soydemir (2014) indicated that that consumer confidence is a significant exogenous variable in determining the residential property price. Based on a study done by Leung, Xu and Tsui (2009), the authors found that consumer confidence affects the expected housing price in the future. Besides that, Chung (2010) and Kim and $\mathrm{Yu}$ (2013) reported that consumer confidence in the housing market influences the movement of the housing transaction price.

Rouwendal and Longhi (2008) found that consumers' confidence has a positive impact on the development of residential property prices. Consumer confidence has become the most important 
determinant of the increase in residential property prices. The authors suggested that increased house demand is associated with an increase in consumer confidence, which leads to a rise in residential property prices. When the current residential property price rises, the buyer will expect a spike in the residential property prices in the future and this impact can sometimes quickly compensate for the detrimental consequences of the growth in the borrowing rate. In contradiction, the drop in consumer confidence towards the housing industry coincided with falling residential property prices. Similarly, Lambertini, Mendicino and Teresa Punzi (2013) discovered that consumers expectations could influence the rise of the property price. The author explained that the real estate market current situation report would influence the consumer's confidence towards the future expectation of property high price.

In the context of Malaysia, there are incremental changes to the residential property price recently and the movement of the property price is driven by the supply and demand factors. Rising consumer confidence in the real estate market would encourage more demand for housing although the current situation of housing supply in Malaysia has grown at a slower pace which causes the residential property price increase (Ferlito, 2018). Similarly, Hamzah, Yazid \& Shamsudin (2020) indicate that consumer confidence and optimism upon future real estate investment had caused the escalating prices of residential property in Malaysia. The situation of rising residential property prices will cause the affordability of consumers in Malaysia to decrease (Lu et al., 2020). However, Mohd Daud and Marzuki (2019) found a contradicted result where weak consumer confidence in the movement of residential property prices in Malaysia is due to other economic factors such as food prices, job security, and health that become consumers' priority concerns.

\subsection{Consumer Confidence and Macroeconomic Drivers}

Previous studies have indicated that consumer confidence is tightly related to macroeconomic factors (Malovana, Hodula \& Frait, 2021; Matosec \& Obuljen Zoricic, 2019; Soric, Zokalj \& Logarusic, 2020). Consumer confidence measures the level of consumer's optimism on income stability and economic growth. Besides that, consumer confidence is also responsive towards other macroeconomic factors such as inflation rate, interest rate movements, stock market developments, and unemployment rate issues. This reveals that macroeconomic factors can explain the variability in consumer confidence. Macroeconomic variables such as gross domestic products (GDP), inflation rate, lending rate, stock market and unemployment rate are considered because they are recognised as standard macroeconomic indicators in related literatures (Golinelli, \& Parigi, 2004; Mohan et al., 2019; Vuchelen, 2004).

\subsection{Macroeconomic Drivers towards Residential Property Prices}

Previous studies indicate that Gross Domestic Product (GDP), money supply, inflation, lending rates, unemployment rates, and stock price are several variables that focus on explaining residential property prices. Real Gross Domestic Product (GDP) is widely recognized as an important economic factor determinant of residential property price movements (Case \& Glaeser, 2000; De Wit \& Van Dijk, 2003; Ong, 2013; Xu, 2017). According to Tsatsaronis and Zhu (2014), real GDP growth has information that contains direct measures of household income and housing prices. Englund and Ioannides (1997) and Valadez (2015) indicated that a change in House Price Index (HPI) will lead to a change in GDP. For example, Englund and Ioannides (1997) reported that a rise in household income is predicted to boost housing demand, and as a result, residential property prices will increase. Similarly, Hii, Latif and Nasir (1999) also suggested that real GDP has a strong connection to the residential property price where the property prices increase with real GDP. However, Tsatsaronis and Zhu (2014) and Ganeson and Abdul Muin (2015) found a contradictory result. The authors found that GDP does not have significant relation with residential property price.

Yoshioka and Yamada (2002) found that the money supply, either directly or indirectly through interest rate and bank credit, played a significant role in determining property prices. Similarly, Fengyun (2013) found that money supply might have influenced an increase in property prices, especially during the real estate bubble period. Trofimov, Aris and Xuan (2018) indicated that the money supply was 
found to have a significant impact on housing prices. A study was done by Barksenius and Rundell (2013) and Lastrapes (2002) that reported a strong relationship between housing prices and money supply in Swedish. The authors explained that due to lower interest rates and user costs, an increase in the money supply may have raised the demand and prices for residential property. However, in contrast, Tsai and Peng (2011) and Xu and Tang (2014) found that money supply has an adverse relationship with residential property prices due to the emergence of housing bubbles and a sharp increase in property prices.

Inflation is also considered as one factor that affects property prices in the real estate market (Cho, 2005). According to Tsatsaronis and Zhu (2014), the importance of inflation in determining the property price suggests that higher inflation would harm the residential property prices for a certain period. The author further described that high inflation can cause a reduction in residential property price growth, especially in the shorter-term period. Nevertheless, inflation and property price can also have a positive relationship whereby it moves in the same direction as residential property prices (Calza, Monacelli \& Stracca, 2013). Williams (2015) also found that a reduction in residential property prices is significant reduction in inflation.

Lending Rate is another important factor determinant of residential property price volatility (Harris, 1989; Qi, 2007; Xu, 2017). Harris (1989) found that housing prices are affected by lending rates. Gasparennienè and Remeikienè (2016) highlighted that the effect of the bank lending rate on housing prices can be considered to have a greater impact. The authors suggest that since the lending rate is the primary source of financing for house purchasing, therefore, it has become one of the important determinants of housing price levels. Generally, the lending rate could encourage household spending and affect the residential property price. According to Xu (2017), an increase in the lending rate will increase the residential property prices and this consequently will encourage an increase in household's demand for bank credit. However, Yun Joe Wong, Man Eddie Hui and Seabrooke (2003) found that high lending rates could increase the household's burden on actual debt payments. Follain (1982) reported that household's liquidity issues tend to lower the demand for housing at high lending rates. Similarly, Sutton and Mihaljek (2017) stated that the increase in lending rate induced by rising funding property costs affected housing demand and eventually can lead to some drop in residential property prices. Likewise, Fama and Schwert (1977) indicate that an increase in lending rate can restrain forecasting and speculation activities in the housing industry.

Several previous studies showed the relationship between labour market indicators such as unemployment rate and housing prices (Abraham \& Hendershott, 1996; Adams \& Fuss, 2010; De Wit, Englund \& Francke, 2013). For example, De Wit, Englund \& Francke (2013) found that the unemployment rate negatively affects residential property prices. The rising unemployment rate due to an increase in non-graduation rates can harm earnings which causes a negative relation to housing market price conditions (Stratton, 2017). According to Pinter (2018), a rise in residential property prices would increase the market value of collateral assets held by businesses, thus allowing them to borrow more money and expand their credit lines. This will result in a decrease in job separation rates, as well as a decrease in the number of unemployed workers seeking jobs and declining the unemployment rate.

Besides that, Johnes and Hyclak (2018) reported that unemployment affects residential property prices and consequently, it also has an indirect effect on the size of the labour force. Thomas (1993) and McCormick (1997) found a significant relationship between credit facilities such as housing loans and the unemployment aspect. The study focuses on the impact of the lower unemployment rate and its connection to the residential property price. Meanwhile, Jacobsen and Naug (2005) indicated that there is no relationship between labour market indicators (such as unemployment rate) and residential property price.

Stock prices have significant impacts on real output and the general price level (Ibrahim, 2010). Ibrahim (2010) indicated that the stability of the stock market is critical for the sustainability of the housing market. Sutton (2002), Borio and McGuire (2004) and Lean (2012) reported that the changes in stock prices and residential property prices were linked. The authors found that property prices are influenced by stock prices. Kapopoulos and Siokis (2005) proposed that under the Wealth Effect mechanism, a household who is aware of a rise in stock prices will have a higher demand for housing, 
increasing residential property prices. Meanwhile, under the Credit-Price Effect, the authors proposed that residential property price increases will improve the financial statement of firms and increase the company's net value. Therefore, as the company's stock price rises, investors are willing to pay the extra price for these companies. However, on the other hand, Batayneh and Al-Malki (2015) found an inverse relationship between stock market prices and residential property prices in Saudi Arabia.

Previous studies showed that the movement of residential property prices in Malaysia is also influenced by several macroeconomic factors. Pinjaman \& Kogid (2020) indicate that macroeconomic variables are significantly influencing residential property in Malaysia. The rise in the level of interest rates, housing supply, and inflation will result in the decline in residential property prices while gross domestic product and local currency appreciation cause the price to increase. Similarly, Yusof, Wahab and Sukrri (2018) found that the Malaysian House Price Index (MHPI) has a significant relationship with employment, interest rate, inflation, and housing loan. Besides that, Sukrri et al. (2019b) reported that macroeconomic factors such as housing loans are identified to be significant in influencing Malaysian residential property prices with positive relationships. In addition, according to Trofimov et al. (2018), gross domestic product and lending rate are negatively related to the prices of residential properties in Malaysia where an increase in the gross domestic product and lending rate dampens property prices.

In conclusion, there are many studies on consumer confidence in property prices. However, to the best of our knowledge, there is no study on the effect of consumer confidence and macroeconomic drivers on residential property prices in Malaysia. Although there is a limited number of studies regarding consumer confidence and property prices in Malaysia, the existing studies did not include macroeconomic variables that studied the behaviour of property prices in the real estate market. In addition, our study differs by focusing on the effect of consumer confidence (as a focus variable) towards residential property prices and macroeconomic drivers (such as Gross Domestic Product, money supply, inflation, lending rates, unemployment rates, and stock price) as control variables on residential property prices. Thus, our study fills the gap in the literature by analysing the effect of consumer confidence on residential property prices in Malaysia.

\subsection{METHODOLOGY}

This study builds on existing literature that deals with buyer behaviour by including consumer sentiment into the ARDL model. A transformation of ARDL can construct an error correction model (ECM) which allows short-run and long-run impacts to be calculated simultaneously in determining the possible effect of consumer sentiment on the price of the property being analysed.

\subsection{Data}

This study utilises quarterly data spanning from 2004 to 2018 for all variables. In this study, we measure Malaysia's residential property price using the Housing Prices Index (HPI). According to Edelstein and Lum (2004), HPI is used to assess variation in residential property prices, that is not influenced by adjustments in the quality or quantity of the housing in the index. The author also indicates that any changes in residential property price which includes macroeconomic factors could affect the current value of the residential property. Besides that, HPI allows anyone to see long-run trends in Malaysia's residential property prices and examines the state of the housing market and real estate industry. Therefore, we obtain HPI data from the Valuation and Property Services Department of Malaysia.

Furthermore, we utilise the Consumer Sentiment Index (CSI) as our main focus variable in this study to measure consumer confidence in the country's housing industry and real estate market. We obtain data on Consumer Sentiment Index from the Malaysia Institute of Economic Research (MIER). Other selected control variables used in this study are Gross Domestic Product (GDP), money supply (MS), inflation (INF), lending rate (LEND), stock price index (STOCK) and unemployment rate (UNEMPLOY) which is obtained from the Department of Statistics Malaysia (DOSM) database. 


\subsection{Model}

To achieve the objective of the study, we utilised an econometric model as discussed in this section. In Equation (1), we estimate Malaysia's house price index as the dependent variable. We employ Malaysia's House Price Index as the dependent variable and Malaysia's Consumer Sentiment Index as our focus independent variable. We control for economic growth, money supply, inflation, lending rate, stock price, and unemployment rate to determine the effect of consumer confidence towards residential property prices. The selection of these macroeconomic variables as control variables is based on the related literatures which focuses on explaining macroeconomic factors affecting residential property prices. According to Grum and Govekar (2016), macro-economic significantly affect the real estate market. Therefore, such variables should be considered as control variables.

Besides that, the stationary properties of the variables are tested using the Augmented DickeyFuller (ADF) unit root test. The ADF examines the null hypothesis that the variable contains a unit root against the alternative that it follows a stationary process. The ADF is an extension of the regular Dickey-Fuller test in the sense that it accounts for some forms of serial correlations (Sadraoui, Deghachi, Aissa, 2016). Besides, Johansen Cointegration Test can be used to determine stable, long-run relationships between sets of variables. This test avoids the problems that arise on deciding a dependent variable, as well as the problems that arise when errors are carried from one step to the next step (Rao, 1994). Furthermore, this test can also detect multiple cointegrating vectors.

In exploring the long-run relationship among residential property prices, consumer sentiment index and other macroeconomic drivers such as economic growth, money supply, inflation, lending rate, stock price, and unemployment rate, autoregressive distributed lag (ARDL) framework are used in this study. Laurenceson and Chai (2003) and Lim and Lau (2018) stated that the ARDL approach uses ample numbers of lags to assess the behaviour of data using the framework of specific modeling, allowing for a different number of lags to be assigned to each variable. Besides that, Dritsakis (2011) indicate that transforming ARDL into an error correction model (ECM) allows for simultaneous estimation of shortrun and long-run impact to be estimated simultaneously. Since the data used in this study are quarterly in selecting an appropriate lag length (p) for the ARDL model, a set of the model was estimated lag length of four. A lag length is preferred where the model has a minimum Akaike information criterion value (Chia and Lim, 2015).

The estimation equations are as follow;

Our research objective is to determine how does consumer confidence towards the housing industry affect residential property price in Malaysia. The relationship between the Housing Price Index (HPI), Consumer Sentiment Index, and macroeconomic drivers are explained in Equation (1) and Equation (2).

The basic form of the model as in Equation (1);

$$
\mathrm{Y}=\beta_{0}+\beta_{1} \mathrm{X}_{1}+\beta_{2} \mathrm{X}_{2} \ldots \ldots+\beta_{\mathrm{k}} \mathrm{X}_{\mathrm{k}}+\varepsilon
$$

Where $Y$ is the House Price Index and $X_{1}$ through $X_{k}$ represent Consumer Sentiment Index and other macroeconomic determinants such as Gross Domestic Product, money supply, inflation, lending rate, stock price index, and unemployment rate. Meanwhile, $\beta_{k}$ refers to the weight or coefficient for each of the $X$ 's.

Then, a detailed explanation of an ARDL model is explained in the following Equation (2);

$$
\begin{aligned}
& \ln H P I_{t}=\beta_{0}+\sum_{i=1}^{p} \beta_{i} \operatorname{lnCSI} I_{t-1}+\sum_{j=0}^{p} \beta_{j} \ln G D P_{t-1}+\sum_{k=0}^{p} \beta_{k} \ln M S_{t-1}+ \\
& \sum_{l=0}^{p} \beta_{l} \operatorname{lnINF}_{t-1}+\sum_{m=0}^{p} \beta_{m} \operatorname{lnLEND_{t-1}}+\sum_{n=0}^{p} \beta_{n} \operatorname{lnSTOCK}_{t-1}+
\end{aligned}
$$


$\sum_{s=0}^{p} \beta_{s} \ln U N E M P L O Y_{t-1}+e_{t}$

(2)

where $H P I$ is the Housing Price Index, $C S I$ is the Consumer Sentiment Index, GDP is Gross Domestic Products, $M S$ is Money Supply, $I N F$ is inflation, $L E N D$ is the lending rate, $S T O C K$ is a stock price index and $U N E M P L O Y$ is the unemployment rate.

Based on the discussion above, the suggested expected signs of the Consumer Sentiment Index and other macroeconomic drivers are shown in Table 1

Table 1: Expected Signs of the Coefficient Variables

\begin{tabular}{lcccc}
\hline Variables & $\begin{array}{c}\text { Factor } \\
\text { element }\end{array}$ & Definition & $\begin{array}{c}\text { Measurement } \\
\text { (unit) }\end{array}$ & Expected sign \\
\hline $\begin{array}{l}\text { Consumer } \\
\text { confidence }\end{array}$ & CSI & $\begin{array}{c}\text { Consumer } \\
\text { Sentiment Index } \\
\text { Gross domestic } \\
\text { product } \\
\text { Money supply }\end{array}$ & $\begin{array}{c}\text { Index point } \\
\text { Real GDP Growth } \\
\text { Rate (Percentage, \%) } \\
\text { Malaysian Ringgit } \\
\text { (RM) }\end{array}$ & Positive \\
Macro- & MS & Positive \\
economic & INF & Ponsumer Price & Positive \\
indicators & LEND & Lending rate & $\begin{array}{c}\text { Index }(\text { Index } \\
\text { point } \\
\text { Percentage, \% } \\
\text { Index point }\end{array}$ & Positive \\
& STOCK & $\begin{array}{c}\text { Stock Price Index } \\
\text { Unemployment rate }\end{array}$ & $\begin{array}{c}\text { Percentage, } \% \\
\text { PNEMPLOY }\end{array}$ & $\begin{array}{c}\text { Positive } \\
\text { Negative }\end{array}$ \\
\hline
\end{tabular}

Sources: Valuation and Property Services Department of Malaysia, Malaysia Institute of Economic Research and Department of Statistics Malaysia

\subsection{RESULT AND DISCUSSION}

Table 2 presents the descriptive statistic of the variables used in the estimation regression of the residential property price model.

Table 2: Descriptive Statistics of Variables

\begin{tabular}{ccccc}
\hline Variables & Mean & Minimum & Maximum & $\begin{array}{c}\text { St. } \\
\text { Deviation }\end{array}$ \\
\hline HPI (in index point) & 153.95 & 114.2 & 193.7 & 12.66 \\
CSI (in index point) & 99.87 & 63.8 & 132.9 & 17.74 \\
GDP (in percentage) & 5.08 & 6.2 & 10.3 & 2.50 \\
MS (in RM) & 252860.35 & 105256.59 & 427720.52 & 103844.4 \\
INF (in index point) & 103.13 & 84.6 & 121.2 & 10.95 \\
LEND (in percentage) & 5.23 & 4.48 & 6.65 & 0.71 \\
STOCK (in index point) & 1421.96 & 819.86 & 1882.71 & 350.23 \\
UNEMPLOY (in & 3.31 & 2.75 & 4.05 & 0.27 \\
percentage) & & & & \\
\hline
\end{tabular}

House Price Index (HPI) calculates average price changes for housing property that are sold or debt restructured by taking into account mortgages purchased or secured. A high HPI index points give an overview of rising residential property prices in the property market and vice versa. Meanwhile, the 
Consumer Sentiment Index (CSI) measures an individual's feelings toward personal financial situation and short term or long term real estate market conditions based on the economic situation. A high CSI index points indicate a positive individual's level of confidence towards the future of real estate market growth, thus he or she is likely to purchase more property. In contrast, if an individual's level of confidence shows uncertainty about the real estate market situation, he or she tends to save money and make fewer discretionary spendings.

The other six macroeconomic drivers (namely Gross Domestic Product, money supply, inflation, lending rate, Stock Price Index, and unemployment rate) are used to determine the performance and outlook of an economy related to the housing market either it is booming or slumping. A good sign of macroeconomic drivers will affect the performance of the residential property market where a strong property market creates more demands and cause property value increases.

Results in Table 3 show that all variables achieved stationary after the first differencing, and indicating that these variables are $I(\mathrm{I})$ process.

Table 3: Stationary Results Based on ADF Unit Root Test

\begin{tabular}{lccc}
\hline Variables & Level (0) & $\begin{array}{c}\text { First Difference } \\
(\mathbf{I})\end{array}$ & Outcome \\
\hline HPI & -2.1924 & $-9.5518^{*}$ & $I(\mathrm{I})$ \\
$\operatorname{lnCSI}$ & -2.8196 & $-9.6242^{*}$ & $I(\mathrm{I})$ \\
$\operatorname{lnGDP}$ & -1.8550 & $-4.5219^{*}$ & $I(\mathrm{I})$ \\
$\operatorname{lnMS}$ & $-3.7335^{*}$ & $-4.4080^{*}$ & $I(0)$ \\
$\ln I N F$ & -1.0748 & $-6.7780^{*}$ & $I(\mathrm{I})$ \\
$\operatorname{lnLEND~}$ & -1.3219 & $-4.9428^{*}$ & $I(\mathrm{I})$ \\
lnSTOCK & -1.4650 & $-6.2669^{*}$ & $I(\mathrm{I})$ \\
lnUNEMPLOY & -2.5049 & $-4.0034^{*}$ & $I(\mathrm{I})$ \\
\multicolumn{4}{c}{ Note: * denotes significant level based on MacKinnon's critical value at 1\%. }
\end{tabular}

The existence of a long-run relationship between two or more variables is evaluated through the medium of the Johansen Cointegration Test to identify the degree to which two variables are sensitive to the same average price over a specific time as in Table 4.

Table 4: Johansen Cointegration Test

\begin{tabular}{lcl}
\hline & Statistic & Probability \\
\hline Trace Statistic: & & \\
None $^{*}$ & 190.7901 & 0.0003 \\
At most 1 & \\
At most 2 & 126.0720 & 0.0469 \\
Maximum Eigenvalue Statistic: & 0.0688 \\
None $^{*}$ & 93.09286 & \\
At most 1 $^{*}$ & 84.71811 & 0.0018 \\
At most 2 & 52.97914 & 0.0773 \\
\hline
\end{tabular}

Table 4 shows the results from the Cointegration Test for both Trace and Maximum Eigenvalue statistics which shows the presence of cointegration of the variables in the model. This indicates the existence of a long-run equilibrium relationship to which the variables converge over time.

The main motivation of this study is to determine how does consumer confidence towards the 
housing industry affect residential property price in Malaysia. For this impetus, we use the log functional form, which can correct heteroscedasticity and multicollinearity problems (Basu and Thibodeau, 1998). Table 5 presents the results of the estimation long-run regression.

Table 5: Estimation of Long-run Results of the Regression

\begin{tabular}{|c|c|c|c|c|}
\hline Variables & Coefficient & Standard Error & T-Stat & P-Value \\
\hline Constant & 23.7194 & 10.8514 & 2.19 & 0.034 \\
\hline $\operatorname{lnHPI}$ & $-0.7451^{* * *}$ & 0.1709 & 4.36 & 0.000 \\
\hline $\operatorname{lnCSI}$ & $0.0934^{* * *}$ & 0.0309 & 3.02 & 0.004 \\
\hline $\operatorname{lnGDP}$ & $0.8148^{*}$ & 0.3552 & 1.55 & 0.105 \\
\hline $\operatorname{lnMS}$ & $1.4527^{*}$ & 0.8346 & 1.62 & 0.101 \\
\hline $\operatorname{lnINF}$ & $-5.0438^{* *}$ & 2.2801 & -2.21 & 0.032 \\
\hline $\operatorname{lnLEND}$ & $3.7561^{* *}$ & 1.2021 & 3.12 & 0.003 \\
\hline $\operatorname{lnSTOCK}$ & 0.0010 & 0.0031 & 0.33 & 0.742 \\
\hline lnUNEMPLOY & $4.9307^{* *}$ & 2.2271 & 2.21 & 0.032 \\
\hline $\begin{array}{l}\text { Error Correction } \\
\text { Term }\end{array}$ & $-0.7451^{* * *}$ & 0.1709 & -4.36 & 0.000 \\
\hline No. of observations & \multicolumn{4}{|c|}{59} \\
\hline Log-Likelihood & \multicolumn{4}{|c|}{114.4504} \\
\hline R-Squared & \multicolumn{4}{|c|}{0.5522} \\
\hline Adjusted R-Squared & \multicolumn{4}{|c|}{0.4474} \\
\hline Root MSE & \multicolumn{4}{|c|}{1.8862} \\
\hline
\end{tabular}

Based on the result in Table 5, the error-correction term was negative and significant, which indicates the presence of long-run adjustments. The coefficient of 0.7451 suggests that residential property prices converged toward equilibrium 75 percent in one quarter through residential property price themselves. It implies that it took more than approximately one quarter $(1 / 0.7451=1.3)$ to eliminate the disequilibrium. Although this shows that residential property prices volatility is not a major issue since 75 percent of disequilibrium is corrected within one quarter, low volatility of residential property price can influence the buyer's confidence to make a quick decision about their choice to buy a residential property, as there is a reasonable possibility of price increase in the short term.

Variable Consumer Sentiments Index (CSI) is positive and statistically significant. The result explains that if the CSI increases by one index point, the residential property price significantly increases by 9.34 percent. This shows that the property sector improves positive consumer sentiment. For example, several discounts and incentives given by the government which could help to reduce the ownership cost for buyers such as stamp duty exemption during the Home Ownership Campaign in 2019 have increased consumer confidence towards the housing industry. As a result, following other government's strategies on housing program schemes, the performance of the housing sector in Malaysia is reported to have improved slightly in terms of transactions. These discounts, incentives and initiatives have raised individual's positive confidence in the future housing industry which enables more Malaysians to buy a house through several housing schemes such as PRIMA, PPA1M and MyHome.

Besides, according to the Malaysian Institute of Estate Agent (MIEA), the positive sign shows a stabilising market for the property sector which indicates the sector is recovering, though at a slower pace. This result is consistent with a study done by Chun (2017). The author found that consumers would describe rising residential property prices as a sign of a thriving real estate market. Thus, indirectly this may increase their confidence in the current real estate market outlook. 
The coefficient of Gross Domestic Product (GDP) is positive and statistically significant. This indicates that an increase in economic activities in Malaysia will drive the demand for residential property that will increase the residential property prices. When the GDP is increasing, it signals that a country's economy is growing well (Peterson, 2017; Chien, Cheng \& Hsu, 2019). This will create more job opportunities for the citizen and generate income level rises, which promote better standard living of household. According to the Department of Statistic Malaysia Report (2019), as the mean salary of Malaysians has increased by 37 percent from 2010 to 2018, the consumer spending patterns for goods and services has also increased up to RM205.9 billion or 40.40 per cent from 2010. In general, salary increment has increased the purchasing power on consumption. Income increases are expected to have a positive effect on residential property demand. This might have caused the property developer to develop more residential properties as the demand for property increases, consequently property prices. This result is consistent with the work of Adams and Fuss (2010) and Liew and Haron (2013) that have proposed that a high gross domestic product led to the increase of property prices.

Also, the coefficient of money supply indicates a positive and statistically significant result. It shows that money supply can influence property demand and it has a strong effect on property prices. In general, a change in money supply results in changes in price levels and the supply of goods and services. A rapid increase in money supply lowers interest rates, which in turn, reduce the financing cost of residential property development (Liu, 2013). This will encourage lending and property investment in the real estate market which leads to higher aggregate demand for housing and ultimately affects residential property prices. Based on the statistic by Bank Negara Malaysia (BNM), from 2010 until 2019 , the money supply indicates a trend of increase up to 31.57 percent. It is supported by a fluctuation of interest rate that does not change from 2011 until 2014 and a decrease in the interest rate of two times, 2016 to 2018 and 2019 until the current time (2020). As a result, demand for new residential property has increased up to 35 percent although only 21 percent are the new property offerings (BNM, 2017). This might have caused the price hike due to a limited supply of property. This result is consistent with studies done by Barksenius and Rundell (2013) and Lastrapes (2002) which reported a positive relationship between residential property prices and money supply.

The coefficient of inflation shows a negative and statistically significant result. It indicates that high inflation consequently causes a reduction in property prices. Generally, inflation is a sustained increase in the general price levels which leads to a reduction in the purchasing power. Interest rates tend to go up with inflation (Cho, 2005). If the interest rates move up, the cost of borrowing becomes more expensive and demand for lending will decline as demand for property will fall. This might have caused the property prices to drop. For example, although the inflation rate in Malaysia was recorded the highest 3.8 percent in 2017 since 2010, nevertheless, the market value of residential property in 2017 had decreased by $12.79 \%$ between Quarter 1 and Quarter 4 (NAPIC, 2017). Furthermore, during the high inflation, an oversupply of residential property may also effectuate the property prices down. This result is consistent with studies done by Tsatsaronis and Zhu (2014) and Cho (2005) where higher inflation would harm residential property prices for a certain period, especially in the shorter-term period.

Besides that, the coefficient of lending rate is positive and statistically significant. This shows that the lending rate is positively correlated with housing prices. According to Khazanah Research Institute (2019), construction costs including labour, materials, machinery and equipment have increased slightly for the past 10 years from 2008 until 2018. The median land price in Malaysia (RM per sq. feet) also has raised to 83.47 percent in a decade. When the property cost increases, the financing cost will also increase leading to the rise in lending rate. As such, disproportionate increases during the inefficiency of the country's property construction industry have caused difficulties for the property developer to maintain a standard profit margin of $15 \%$ of Gross Development Value (GDV) to be able to sustain in the housing industry. Therefore, as a result, the housing supply decline and housing prices increase. This result is consistent with Liew and Haron (2013) and Guo and Wu (2013). The authors reported that as the demand for housing increased with limited supply, this had led the residential property price to rise. Moreover, reduced consumer confidence towards banks affects bank lending, 
which shows the decline in consumer borrowing. As the demand for property declines, limited supply for residential property project will lower the property price.

Interestingly, the coefficient of the stock price index is statistically insignificant. This indicates that the stock price does not affect the residential property prices which stimulate the increase or decrease in financial wealth which does not foster investment in the housing industry. The possible explanation is that any wealth shift from the stock market to the real estate market due to the profits gained from investments in the stocks market will not necessarily be reinvested in the housing industry in Malaysia. Additionally, Forbes has listed the energy industry, food and beverages (F\&B) industry and technology industry as the top three best industries to invest in compared to the housing industry in 2019 (Russo, 2019).

Surprisingly, the coefficient of the unemployment rate shows a positive and statistically significant result, which contradicts the economic theory. The possible explanation for this contradictory result is when an individual loses a job, he or she will have less disposable income and this might have caused the household to move into a low-cost houses. Consequently, this will create more demand for low-cost house. Based on the Property Market Report 2019 prepared by the National Property Information Centre (NAPIC), the existing supply for the low-cost house only covers 20.30 percent of the total market (NAPIC, 2018). Therefore, given the situation of a limited supply of low-cost house in Malaysia, if the unemployment rate rises, there will be a surge in demand for low-cost houses and this affects the price of the low-cost house to increase. Cohen and Karpaviciute (2017) also assumed that the unemployment situation could have a positive relationship with disposable income and expensive property.

\subsection{CONCLUSION}

This paper investigates the factor determinants of residential property price from the perspective of consumer sentiment towards the housing industry and macroeconomic drivers. First, the empirical results have shown that consumer sentiment and many macroeconomic variables significantly affect residential property prices. This is in line with previous empirical work done by Chung (2010), Liew and Haron (2013), Kim and Yu (2013), Peterson (2017) and Pillaiyan (2015). Consumer sentiment, GDP, money supply, inflation, lending rate and unemployment rate have a positive or negative effect on property price. Second, the result also suggests that consumer sentiment, GDP, inflation, money supply and lending rate effect on residential property price is consistent with the economic theory. However, only unemployment rate showed contradictory results with the theory.

This paper focuses on the importance of consumer confidence and the real estate market. Consumer's positive confidence in the future housing industry signals the industry is recovering and improving. The expectation of strong economic growth in the future has a significant influence on current levels of consumer confidence in the housing industry. The analysis suggests that residential property price growth will make households feeling more optimistic. The impact of residential property price growth upon consumer confidence will reflect the price expectations. Positive consumer sentiment could result in consumption growth, and consequently in the growth of the real estate market. However, some of the macroeconomic factors such as rising interest rates and an increasing level of mortgage debt can cause reduce consumer confidence.

Policymakers in Malaysia should play a vital role to assist the Government in overcoming the issue of the increase in residential property prices. As the property prices increase, this could result in a significant rise in the amount of money spent on monthly repayment by first-time buyers. Consumers might appear to adopt a wait-and-see attitude as they are worried about the economic condition and imbalance demand-supply situation. Prudent action should be taken by Malaysia to avoid financial instability due to the housing bubble from happening. Over the past decade, the Malaysian government has adopted a variety of housing policies to encounter the issues of rising housing prices which include low-cost housing stimulus package, as well as leaner credit restrictions to the borrower due to financial 
deepening to improve consumer confidence and demand in the housing industry. Apart from that, the government and Bank Negara Malaysia (BNM) should adopt positive measures to address the residential property affordability issues among graduates due to low salaries and negative growth in real salary for early-career graduates. Furthermore, a reliable analysis on measurement and implementation of a residential property price sentiment index based on the Malaysia housing study would be valuable to represent consumer's confidence towards demand and supply of residential property in the real estate market and would be a major signal of real estate market movements.

\section{Acknowledgement}

The corresponding author wishes to thank the Universiti Utara Malaysia (UUM) for funding this study under the College Research Grant (Kod SO: 14550). The views expressed in this study are those of the authors and do not necessarily reflect the views or policies of the ministry. Any errors are the sole responsibility of the authors.

\subsection{REFERENCE}

1. Ab Majid, R., Said, R., \& Chong, J.T.S. (2017). Assessment of bubbles in the Malaysian housing market. Journal of the Malaysian Institute of Planners, 15(3), 27-38.

2. Abraham, J.M., \& Hendershott, P. (1996). Bubbles in metropolitan housing markets. Journal of Housing Research, 199-208. Doi: 10.3386/w4774

3. Adams, Z., \& Fuss, R. (2010). Macroeconomic determinants of international housing markets. Journal of Housing Economics, 19(1), 38-50. https://doi.org/10.1016/j.jhe.2009.10.005

4. Ariyawansa. R. (2010). An empirical study of consumer behavior in housing market in Colombo. Built-Environment Sri Lanka, 8(1), 11-19. Doi: 10.4038/besl.v8i1.1906

5. Bank Negara Malaysia (BNM). (2017). Rencana 2: Ketidakseimbangan dalam Pasaran Harta Tanah. Buletin Suku Tahunan. Retrieved June 8, 2020 from https://www.bnm.gov.my/files/publication/qb/2017/Q3/p3_ba2_bm.pdf

6. Barksenius, A., \& Rundell, E. (2013). House Prices for Real - The Determinants of Swedish Nominal Real. Unpublished Master Thesis. University of Gothenburg, Sweden.

7. Basu, S., \& Thibodeau, T.G. (1998). Analysis of spatial autocorrelation in house prices. The Journal of Real Estate Finance and Economics, 17, 61-85. https://doi.org/10.1023/A:1007703229507

8. Batayneh, K., \& Al-Malki, A. (2015). The relationship between house prices and stock prices in Saudi Arabia: An empirical analysis. International Journal of Economics and Finance, 7(2), 156-167. https://doi.org/10.5539/ijef.v7n2p156

9. Bordalo, P., Gennaioli, N., \& Shleifer, A. (2018). Diagnostic expectations and credit cycles. Journal of Finance, 73(1), 199-227. https://doi.org/10.1111/jofi.12586

10. Borio, C. \& McGuire, P. (2004). Twin peaks in equity and housing prices? BIS Quarterly Review March, 79-93.

11. Calza, A., Monacelli, T., \& Stracca, L. (2013). Housing finance and monetary policy. Journal of the European Economic Association, 11, 101-122. https://10.1111/j.15424774.2012.01095.x 
e-issn: $2229-8568$

12. Case, K.E., Glaeser, E.L., \& Parker, J.A. (2000). Real estate and the macroeconomy. Brookings Papers on Economic Activity, 2, 119-162.

13. Ciarlone, A. (2015) House price cycles in emerging economies. Studies in Economics and Finance, 32(1), 17-52. https://doi.org/10.1108/SEF-11-2013-0170

14. Cheong, C.W.H., Ngui, L.L.H., \& Beatrice, S.G. (2018). On Malaysian house price growth: The effects of market sentiments. Asian Journal of Finance \& Accounting, 10(2), 167-191.

15. Chia, J. Harun, A., Mohd Kassim, A.W., Martin, D., \& Kepal, N. (2016). Understanding factors that influence house purchase intention among consumers in Kota Kinabalu : An application of Buyer Behavior Model Theory. Journal of Technology Management and Business, 3(2), 94110 .

16. Chia, R.C.J., \& Lim, S.Y. (2015). Malaysia stock price and macroeconomic variables: Autoregressive Distributed Lag (ARDL) bound test. Kaji Malaysia, 33(1), 85-103.

17. Chien, M., Cheng, C., \& Hsu, Y. (2019). The impacts of financial freedom on international real estate securities. Universal Journal of Accounting and Finance, 7(4), 83 - 95. https://doi.org/10.13189/ujaf.2019.070401

18. Cho, D. (2005). Interest Rate, Inflation, and Housing Price: With an Emphasis on Chonsei Price in Korea. (NBER Working Paper Series No. 11054). Cambrige: National Bureau of Economic Research.

19. Chun, H. (2017). A study on the impact of changes in consumer sentiment on the housing market in Korea. International Journal of Urban Sciences, 21(2), 129-146. https://doi.org/10.1080/12265934.2016.1239548

20. Chung, E.C. (2010). Consumer sentiment and housing market activities: Impact on sales price of housing. Journal of the Korea Real Estate Analysts Association, 16(3), 5-20.

21. Cohen, V., \& Karpaviciute, L. (2017). The analysis of the determinants of housing prices. Independent Journal of Management and Production, 8, 49-63. https://doi.org/10.14807/IJMP.V8I1.521

22. De Wit, I. \& Van Dijk, R. (2003). The global determinants of direct office real estate return. Journal of Real Estate Finance \& Economics, 26(1), 27-45. https://doi.org/10.1023/A:1021518130915

23. De Wit, E.R., Englund, P., \& Francke, M.K. (2013). Price and transaction volume in the Dutch housing market. Regional Science and Urban Economics, 43, 220-241. https://doi.org/10.1016/j.regsciurbeco.2012.07.002

24. Dritsakis, N. (2011). Demand for money in Hungary: An ARDL approach. Review of Economics and Finance, 1-16.

25. Dua, P., \& Smyth, D.J. (1995). Forecasting US home sales using BVAR models and survey data on households' buying attitudes for homes. Journal of Forecasting, 14, 217-227. https://doi.org/10.1016/0024-6301(95)94329-W

26. Edelstein, R.H., \& Lum, S.K. (2004). House prices, wealth effects, and the Singapore macroeconomy. Journal of Housing Economics, 13, 342-367. https://doi.org/10.1016/j.jhe.2004.09.006 
e-issn: $2229-8568$

27. Englund, P., \& Ioannides, Y.M. (1997). House price dynamics: An international empirical perspective. Journal of Housing Economics, 6(2), 119-136. https://doi.org/10.1006/jhec.1997.0210

28. Fama, E.F., \& Schwert, G.W. (1977). Asset returns and inflation. Journal of Financial Economics, 5, 115-46. https://doi.org/10.1016/0304-405X(77)90014-9

29. Fengyun, L. (2013). The dynamic effects of money supply on real estate prices in the Japanese pre-bubble and bubble period: Compared with recent China. The Ritsumeikan Economic Review, 62(4), 64-84.

30. Ferlito, C. (2018). Affordable Housing and Cyclical Fluctuations: The Malaysian Property Market. Policy IDEAS, No. 51, Institute for Democracy and Economic Affairs (IDEAS). Kuala Lumpur, Malaysia.

31. Follain, J.R. (1982). Does inflation affect real behavior: The case of housing. Southern Economic Journal, 48(3), 570-582. https://doi.org/10.2307/1058651

32. Ganeson, C., \& Abdul Muin, I.M. (1999). An Analysis of the Factors Affecting House Prices in Malaysia - An Econometric Approach. Paper presented at Conference Proceedings of Social Sciences Postgraduate International Seminar (SSPIS). School of Social Sciences, Pulau Pinang, Malaysia, 224-235.

33. Gasparėnienè, L, \& Remeikienè, R. (2016). Skuka. Assessment of the impact of macroeconomic factors on housing price level: Lithuanian case. Intellectual Economics, 10, 122-127. https://doi.org/10.1016/j.intele.2017.03.005

34. Gibler, K.M., \& Nelson, S.L. (1998). Consumer Behavior Applications to Real Estate. Paper presented at the American Real Estate Society Meeting, California.

35. Golinelli, R. \& Parigi, G. (2004), Consumer sentiment and economic activity: A cross country comparison. Journal of Business Cycle Measurement and Analysis, 2004 (2), https://doi.org/10.1787/jbcma-v2004-art10-en.

36. Goodman, J.L. (1994). Using attitude data to forecast housing activity. Journal of Real Estate Research, 9(4), 445-453.

37. Grum, B., \& Govekar, D.K. (2016). Influence of macroeconomic factors on prices of real estate in various cultural environments: Case of Slovenia, Greece, France, Poland and Norway. Procedia Economics and Finance, 39, 597-604. https://doi.org/10.1016/S2212-5671(16)303045

38. Guo, M., \& Wu, Q. (2013). The empirical analysis of affecting factors of Shanghai housing prices. International Journal of Business and Social Science, 4(14), 218-223.

39. Hamzah, A., Yazid, M.F.M, \& Shamsudin, M.F. (2020). Post Covid-19: What next for real estate industrial sector in Malaysia? Journal of Postgraduate Current Business Research, 1, 14

40. Hashim, Z.A. (2010). House price and affordability in housing in Malaysia. Akademika, 18, $37-$ 46.

41. Harris, J. (1989). The effect of real rate of interest on housing price. Journal of Real Estate Finance and Economics, 2(1), 47-60. https://doi.org/10.1007/BF00161716 
42. Hii, J.H.W., Latif, L.A., \& Nasir, M.A. (1999). Lead-lag relationship between housing and gross domestic product in Sarawak. The International Real Estate Society Conference, 26-30.

43. Howard, J.A., \& Sheth, J.N. (1969). The Theory of Buyer Behavior. New York: John Wiley and Sons.

44. Ibrahim, M.H. (2010). House price-stock price relations in Thailand: An empirical analysis. International Journal of Housing Markets and Analysis, 3(1), 69-82. https://doi.org/10.1108/17538271011027096

45. Ismail, N.H., Karim, M.Z.A., \& Hasan-Basri, B. (2019). Hedonic analysis of the impact of flood events on residential property values in Malaysia: A study of willingness to pay. Malaysian Journal of Economic Studies, 56(1), 63-84. https://doi.org/10.22452/MJES.vol56no1.4

46. Jacobsen, D.H., \& Naug, B.E. (2005). What drives house prices? Norges Bank. Economic Bulletin, 76(1), 29.

47. Jin, C., Soydemir, G., \& Tidwell, A. (2014). The U.S. housing market and the pricing of risk: Fundamental analysis and market sentiment. Journal of Real Estate Research, 36(2), 187-220.

48. Johnes, G., \& Hyclak, T. (1999). House prices and regional labor markets. The Annals of Regional Science, 33(1), 33-49. https://doi.org/10.1007/s001680050091

49. Kamakura, W., \& Gessener., G. (1986). Consumer sentiment and buying intentions revisited: A comparison of predictive usefulness. Journal of Economic Psychology, 7, 197-220. https://doi.org/10.1016/0167-4870(86)90004-8

50. Kapopoulos, P., \& Siokis, F. (2005). Stock and real estate prices in Greece: Wealth versus credit price effect. Applied Economics Letters, 125-128. https://doi.org/10.1080/1350485042000307107

51. Kim, D.W., \& Yu, J.S. (2013). An analysis on how psychological attitudes on the house price affect the trading volume. Housing Studies Review, 21(2), 73-92.

52. King, M. (1990). Is the U.K. balance of payments sustainable? Economic Policy, 5, 348-95. https://doi.org/10.2307/1344481

53. Lambertini, L., Mendicino, C., \& Teresa Punzi, M. (2013). Leaning against boom-bust cycles in credit and housing prices. Journal of Economic Dynamics and Control, 37(8), 1500-1522. https://doi.org/10.1016/j.jedc.2013.03.008

54. Lastrapes, W.D. (2002). The real price of housing and money supply shocks: Time series evidence and theoretical simulations. Journal of Housing Economics, 11(1), 40-74. https://doi.org/10.1006/jhec.2002.0309

55. Laurenceson, J., \& Chai, J.C.H. (2003). Financial reforms and economic development in China. Cheltenham, UK, Edward Elgar.

56. Lean, H.H. (2012). Wealth effect or credit-price effect? Evidence from Malaysia. Procedia Economics and Finance, 1, 259-268. https://doi.org/10.1016/S2212-5671(12)00030-5

57. Leung, A.Y.T., Xu, J., \& Tsui, W.S. (2009). A heterogeneous boundedly rational expectation model for housing market. Applied Mathematics and Mechanics, 30, 1305-1316. https://doi.org/10.1007/s10483-009-1010-1 
58. Liew, C., \& Haron, N.A (2013). Factors influencing the rise of house price in Klang Valley. International Journal of Research in Engineering and Technology, 2(10), 261-272.

59. Ling, C.S., Almeida, S.J., \& Wei, H.S. (2018). Affordable Housing: Challenges and the Way Forward. Bank Negara Malaysia Quarterly Bulletin. Retrieved February 16, 2020 from http://www.bnm.gov.my

60. Lim, J.H., \& Lau, W.Y. (2018). The nexus between residential property prices, bank lending, construction output and interest rate: Policy lessons from Malaysia. International Journal of Economics and Management, 12(2), 523-535.

61. Liu, F. (2013). The dynamic effects of money supply on commercialized building prices in China. Journal of Chinese Economic Studies, 10(1), 20-27.

62. Loudon, D.L., Albert, J., \& Della Bitta, A.J. (1993). Consumer Behavior: Concepts and Applications (4th ed.). New York: McGraw-Hill.

63. Lu, A.C.C, Kueh, J., Wei, Y.S., Yau, J. \& Liwan, A. (2020). Impact of foreign direct investment (FDI) on Housing Affordability Index: Vector autoregressive model. Journal of International Business, Economics and Entrepreneurship, 5(2), 1-11.

64. Malaysia National Property Information Centre (NAPIC) (2017). Property Stock Report 2017. Retrieved May 24, 2021 from http://napic.jpph.gov.my/portal

65. Malaysia National Property Information Centre (NAPIC) (2018). Property Stock Report 2018. July 4, 2020 from http://napic.jpph.gov.my/portal

66. Malovaná, S., Hodula, M. \& Frait, J. (2021). What does really drive consumer confidence? Social Indicator Research, 155, 885-913. https://doi.org/10.1007/s11205-021-02626-6

67. Marcato, G., \& Nanda, A. (2016). Information content and forecasting ability of sentiment indicators: Case of real estate market. Journal of Real Estate Research, 38(2).

68. Matosec, M. \& Obuljen Zoricic, Z. (2019). Identifying the interdependence between consumer confidence and macroeconomic developments in Croatia. Interdisciplinary Description of Complex Systems, 17(2-B), 345-354. https://doi.org/10.7906/indecs.17.2.10

69. McCormick, B. (1997). Regional unemployment and labour mobility in the UK. European Economic Review, 41(3), 581-589. https://doi.org/10.1016/S0014-2921(97)00024-X

70. Mohan, S., Hutson, A., MacDonald, I. \& Lin, C.C. (2019). Impact of macroeconomic indicators on housing prices. International Journal of Housing Markets and Analysis, 12(6), 1055-1071. https://doi.org/10.1108/IJHMA-09-2018-0070

71. Mohd Daud, S., \& Marzuki, A. (2019). An unobserved component analysis of Malaysia's house prices. International Journal of Housing Markets and Analysis, 12(3), 353-376. https://doi.org/10.1108/IJHMA-03-2017-0024

72. Ong, T.S. (2013). Factors affecting the price of housing in Malaysia. Journal of Emerging Issues in Economics, Finance and Banking, 1(5), 414-429.

73. Pillaiyan. S. (2015). Macroeconomic drivers of house prices in Malaysia. Canadian Social Science, 11(9), 119 - 130. http://dx.doi.org/10.3968/7482

74. Pinjaman, S., \& Kogid, M. (2020). Macroeconomic determinants of house prices in Malaysia. 
Jurnal Ekonomi Malaysia, 54(1), 153-165. http://dx.doi.org/10.17576/JEM-2020-5401-11

75. Pinter, G. (2018). House Prices and Job Losses. The Economic Journal, 29(618), 991-1013. https://doi.org/10.1111/ecoj.12613

76. Peterson, E.W.F. (2017). The role of population in economic growth. SAGE Open, 7(4), 1-15. https://doi.org/10.1177\%2F2158244017736094

77. Qi, L., \& Hua, C. (2007). Property prices and bank lending in China. Journal of Asian Economics, 18(1), 63-75. https://doi.org/10.1016/j.asieco.2006.12.013

78. Rani, P. (2014). Factors influencing consumer behaviour. International Journal of Current Research and Academic Review, 2(9), 52-61.

79. Rao, B.B. (1994). Cointegration: for the Applied Economist. Palgrave Macmillan, United Kingdom.

80. Realia Group (2019). Ober-House Property Market Report Baltic States. Retrieved Mac 29, 2020 from https://www.pwc.com/ee/et/publications/pub/Ober-Haus-Market-Report-BalticStates-2019.pdf

81. Rouwendal, J., \& Longhi, S. (2008). The effect of consumers' expectations in a booming housing market: Space-time patterns in the Netherlands, 1999-2000. Housing Studies, 23(2), 291-317. https://doi.org/10.1080/02673030801893107

82. Russo, T. (2019). 12 Stocks To Buy For 2019. Retrieved August 19, 2020 from https://www.forbes.com/sites/investor/2019/01/01/12-stocks-to-buy-for-2019/\#5698ee807e8f

83. Sadraoui, T., Deghachi, B., \& Aissa, R.B. (2016). A new cointegration econometric analysis for contagious and volatility spillovers of subprime crisis effects. International Journal of Econometrics and Financial Management, 4(2), 29-38. Doi: 10.12691/ijefm-4-2-1

84. Soric, P., Zokalj, M., \& Logarusic, M. (2020). Economic determinants of Croatian consumer confidence: Real estate prices vs. macroeconomy. Interdisciplinary Description of Complex Systems, 18(2-B), 241-257. http://dx.doi.org/10.7906/indecs.18.2.12

85. Stratton, L.S. (2017). Housing Prices, Unemployment Rates, Disadvantage, and Progress toward a Degree. Discussion Paper Series, No. 10941.

86. Sukrri, N.N.A.N.M., Wahab, N.A. \& Yusof, R.M. (2019b). Constructing an enhanced house price index model: Empirical evidence. Jurnal Ekonomi Malaysia, 53(3), 117-128

87. Sutton, G.D. (2002). Explaining changes in house prices. BIS Quarterly Review September, 4655 .

88. Sutton, G.D., Mihaljek, D., \& Subelyte, A. (2017). Interest Rates and House Prices in the United States and Around the World. BIS Working Papers, No 665.

89. Yun Joe Wong, T., Man Eddie Hui, C., \& Seabrooke, W. (2003). The impact of interest rates upon housing prices: an empirical study of Hong Kong's market. Property Management, 21(2), 153-170. https://doi.org/10.1108/02637470310478891

90. Thomas, A. (1993). The influence of wages and house prices on British interregional migration decisions. Applied Economics, 25(9), 1261-1268. https://doi.org/10.1080/00036849300000106 
e-issn: $2229-8568$

91. Tsai, I.C., \& Peng, C.W. (2011). Bubbles in the Taiwan housing market: The determinants and effects. Habitat International, 35(2), 379-390. https://doi.org/10.1016/j.habitatint.2010.11.010

92. Tsatsaronis, K., \& Zhu, H. (2014). What drives housing price dynamics: Cross-country evidence. BIS Quarterly Review March.

93. Trofimov, I.D., Aris, N., \& Xuan, C.D. (2018). Macroeconomic and Demographic Determinants of Residential Property Prices in Malaysia. MPRA Paper No. 85819.

94. Valadez, R.M. (2015). The housing bubble and the GDP: A correlation perspective. Journal of Case Research in Business and Economics, 1-18.

95. Vuchelen, J. (2004). Consumer sentiment and macroeconomic forecasts. Journal of Economic Psychology, 25 (4), 493-506,https://doi.org/10.1016/S0167-4870(03)00031-X.

96. Weber, W., \& Devaney, M. (1996). Can consumer sentiment surveys forecast housing starts? Appraisal Journal, 4, 343-350.

97. Williams, J.C. (2015). Measuring the Effects of Monetary Policy on House Prices and the Economy. Presentation to Bank Indonesia-BIS Conference on Expanding the Boundaries of Monetary Policy in Asia and the Pacific on 19-21 August 2015 at Jakarta, Indonesia.

98. White, M. (2015). Cyclical and structural change in the UK housing market. Journal of European Real Estate Research, Vol.8, No.1, 85-103. https://doi.org/10.1108/JERER-02-20140011

99. Xu, T. (2017). The relationship between interest rates, income, GDP growth and house prices. Research in Economics and Management, 2(1), 30-37. https://doi.org/10.22158/REM.V2N1P30

100. Xu, L., \& Tang, B. (2014). On the determinants of UK house prices. International Journal of Economics and Research, 5, 57-64.

101. Yin, Y.C., Hui Nee, A.Y., \& Senadjki, A. (2019). The nexus between housing glut, economic growth, housing affordability and house price in Malaysia. Journal of the Malaysian Institute of Planners, 17(1), 267 - 279. http://dx.doi.org/10.21837/pm.v17i9.604

102. Yoshioka, T., \& Yamada, H. (2002). A time series analysis of Japanese land prices after the war. The Journal of Japan Association for Real Estate Science, 16(2), 54-64.

103. Yusof, R.M., Wahab, N.A., Sukrri, N.N.A.N.M. (2018). Enhancing the House Price Index model in Malaysia towards a maqasid shariah perspective: An empirical investigation. $\mathrm{Al}$ Shajarah, 23(2), 225-253. 